\title{
EMOTIONAL INTELLIGENCE OF FEMALE UNDERGRADUATE STUDENTS IN RELATION TO PERCEIVED PARENTING STYLES
}

\author{
Ms. Jaspreet Kaur* \\ Dr. Gurmit Singh**
}

\begin{abstract}
The study was conducted to examine the emotional intelligence of female undergraduate students in relation to perceived parenting styles. The sample comprised of 64 female undergraduate students studying in a randomly selected (using lottery method) private degree college of Chandigarh affiliated to Panjab University. The data was collected using the Sevenfold Emotional Intelligence Scale by Kaur (2016) and Parenting Style Scale byGupta and Mehtani (2017). There existed prevailing democratic parenting style as perceived by female undergraduate students. Significant differences were observed as higher emotional intelligence was witnessed among humanities as compared to commerce female undergraduate students. No significant correlation existed between emotional intelligence andall the parenting styles as perceived by female undergraduate students.
\end{abstract}

Keywords: Chandigarh, Emotional Intelligence, Female, Parenting Styles (Democratic, Autocratic, Permissive and Uninvolved), Undergraduates.

\section{INTRODUCTION}

\section{Emotional Intelligence}

The construct of emotional intelligence has been brought into reality by the efforts of academicians and the business world in the contemporary era. This led to the demand for the incorporation of emotional intelligence competencies in the university curriculum to acquaint students with the skills of managing emotions (Chaubey \& Kala, 2012). Mayer and Salovey (1997) posited that particularly emotional intelligence competencies were needed by students to succeed throughout their life. The concept constituted from the work of Gardner (1983) who explicated it as both intrapersonal and interpersonal ability which implies having the ability to know and understand one's own emotions as well as other individual's emotions 
and intentions. Mayer, Caruso and Salovey (1999) defined emotional intelligence as "an ability to recognize the meanings of emotion and their relationships, and to reason and problem-solve on the basis of them." Kunnanatt (2004) defined emotional intelligence as "the sum total of the mental capabilities that enable a person in understanding his or her own and others' emotions correctly, in real-time, and using these emotions intelligently to produce personally and socially desirable transactional outcomes. From a practical point of view, emotional intelligence is the application of emotions wisely in situations that call for emotionally guarded rather than logically smarter responses." Emotional intelligence is crucial especially in educational ventures and with proper training; students can become successful and well-adjusted members of the community (Holt \& Jones, 2005). Yousefi (2006)found no significant difference between the emotional intelligence of both maleand female students. Walsh-Portillo (2011) in his study concluded that female students revealed significant gains in their overall emotional quotient intelligence scores. Biradar and Shashikumar (2014) in their study depicted that there were no significant differences between male and female students especially on the components of emotional intelligence i.e. self-awareness, emotional resilience, motivation, interpersonal sensitivity, influence, intuitiveness and conscientiousness. Moshahid (2017) in his study concluded that there was no significant difference between the level of emotional intelligence of management and engineering students. However, there was a significant difference between the level of emotional intelligence of management and engineering male students as well as between the management male and female students. There was no significant difference between the level of emotional intelligence of management and engineering female students as well as between the level of emotional intelligence of engineering male and female students. Jayashree, Vimal Ram and Arun (2018)in their study on the emotional intelligence of college students reported that the female studentshad higher emotional intelligence than male students. Fida, Ghaffar, Zaman and Satti (2018) in their study on university students revealed from mean scores that female learners were better than male learners on all dimensions and on 'overall emotional intelligence'. Specifically, in the faculty cluster, the female learners belonging to business and economics as well as chemical and life sciences dominated the different aspects of emotional intelligence. Mostly in every faculty, female students scored higher than the males except in the faculty of business and economics where male students were better only on 'useof emotion' aspect. Similarly, male students of chemical and life sciences were slightly superior to females on 'others emotion appraisal' aspect only. 


\section{Parenting Styles}

The concept of parenting style evolved from the work of Baumrind (1966). Darling andSteinberg (1993) defined parenting style as "a constellation of attitudes toward the child that are communicated to the child and that, taken together, create an emotional climate in whichthe parent's behaviors are expressed.' As cited in Lau, Beilby, Byrnes and Hennessey (2012) parenting style imply to the "patterns of child rearing evolved from parents' reactions towards their child." Park, Kim, Chiang and Ju (2010) in their study on Asian American college students revealed that ratings of parenting styles were highest for authoritarian style, followed by authoritative and permissive styles. Zakeri and Karimpour (2011) in their studyon university students depicted that the mean score of girls was significantly higher than the boys in the "behavioural strictness-supervision" style. But no significant difference between girls and boys in "acceptance-involvement" and "psychological autonomy-granting" parenting styles were witnessed. Barnhart, Raval, Jhansari and Raval (2012) in their study contrary to their expectation, revealed that Indian college students considered their parents demonstrating permissive parenting to be more effective and helpfulin contrast to United States college students who considered their parents demonstrating authoritative and authoritarian parenting to be more effective, helpful and caring. Lin and Billingham (2014) in their study reported significant differences in parenting styles between gender role groups. Maternal and paternal authoritativeness was associated with participants' femininity and for both parents and it was observed to be stronger in males as compared to females. Also, paternal authoritativeness was significantly related to androgyny. Cho and $\mathrm{Oh}$ (2019) in their study using the cluster analysis identified three types of parenting styles of affectionate intimate group, excessive involved group and uninvolved group.

\section{Emotional intelligence and Parenting Styles}

Nastasa and Salab (2012) revealed that a statistically significant negative correlation existed between the development of emotional intelligence and the authoritarian parental style as well as the dictatorial parental style. The permissive and democratic parental styles werepositively and statistically significantly correlated with the level of development of emotional intelligence. Mohammadyari and Sherzvani (2013) in their study on undergraduate psychology students concluded that the mean emotional intelligence scores of students varied based on their parental style. Further, Tokay's test revealed that students with authoritative and permissive parental styles had higher emotional intelligence than students with neglecting parental style. Khajeh and Shayof (2015) intheir study depicted that parenting styles had a significant relationship with emotional intelligence of students further they anticipated the variance of emotional 
intelligence wherein the authoritative parenting style was the strongest positive predictor while authoritarian and permissive parenting styles were negative predictors of emotional intelligence. Wischerth, Mulvaney, Brackett and Perkins (2016) in their study indicated that emotional intelligence was negatively associated with permissive parenting. It was further revealed the negative impact of permissive parenting upon personal growth was mediated by emotional intelligence. Argyriou, Bakoyannis and Tantaros (2016) in their study depicted an association between parenting styles and trait emotional intelligence. It was statistically significant for authoritativeness and marginally significant for authoritarianism. Cameron, Cramer and Manning (2020) revealed that emotional intelligence was higher for those raised authoritatively and permissively than for those raised by authoritarian or neglecting parenting styles thus, indicating that the responsiveness and levels of support characteristic of these styles had the strongest positive relation to adult emotional intelligence.

\section{NEED OF THE STUDY}

Emotions assist individuals' in recognizing and analyzing personal achievements. It includes the ability to convince, enthuse, motivate, channelize and comprehend one's as wellas others' emotions. Parenting, on the other hand, plays a crucial role in students' transition from childhood to adulthood. It has a major influence on the socializationof the child. Researches carried out in the past too have tried to unfold convincing links between parenting styles and emotional intelligence. Several studies have examined the relations between parenting styles and emotional intelligence from the elementary to the adolescence level but only a handful few; when they enter the phase of transition i.e. college. The research studies have revealed that there is a strong emphasis on the importance of family, especially parents, influencing the child's emotions and their management. Also, parenting practices are different for females as compared to males. The purpose of this study is to examine the emotional intelligence of female undergraduates in relation to perceived parenting styles. A review of the literature didn't offer any conclusive results which motivated the investigator to take up the current study. This study can help to provide a perspective in understanding the need for the involvement of the parents in parenting tasks and their influence on the emotions especially of the female students alongwith its related outcomes.

\section{OBJECTIVES}

The study was conducted with the following objectives:

- To study the prevailing parenting style (i.e. democratic, autocratic, permissive and uninvolved) as perceived by female undergraduate students.

- To study the differences in emotional intelligence of humanities and commerce female 
undergraduate students.

- To study the relationship between emotional intelligence and perceived parenting styles (i.e. democratic, autocratic, permissive and uninvolved) as perceived by female undergraduate students.

\section{HYPOTHESES}

On the basis of the above objectives, the following hypotheses were formulated:

- There exists a prevailing parenting style (i.e. democratic, autocratic, permissive and uninvolved) as perceived by female undergraduate students.

- There exist no significant differences in emotional intelligence of humanities and commerce female undergraduate students.

- There exists no significant correlation between emotional intelligence and parenting styles (i.e. democratic, autocratic, permissive and uninvolved) as perceived by female undergraduate students.

\section{DELIMITATIONS OF THE STUDY}

The study was delimited to first year female undergraduate students studying in the humanities and commerce streams in a private degree college of Chandigarh affiliated toPanjab University.

\section{METHODOLOGY}

\section{RESEARCH METHOD}

Descriptive survey method has been used in the present study. It attempts to establish the range and distribution of certain social characteristics and discovering how these featuresmay be related to some behavioural patterns or attitudes (Descriptive Survey, 1981). In this study, data was collected through questionnaires in order to evaluate and explicate the concepts further.

\section{TOOLS USED}

In the present study, the following tools have been used:

- Sevenfold Emotional Intelligence Scale: As devised by Kaur (2016) it is a five-point scale consisting of 63 questions related to dimensions namely self-awareness and appraisal, self-regulation and responsibility, self-motivation, self-esteem andconfidence, empathy and acceptance of others, interpersonal relations lastly, social skills.

- Parenting Style Scale: As devised by Gupta and Mehtani (2017) it is a five-point scale consisting of 44 questions related to dimensions namely democratic, autocratic, permissive and uninvolved. 


\section{SAMPLE}

The population of the study was first-year undergraduate students studying at Punjab University and its affiliated colleges in Chandigarh. The sample was collected much before the announcement of the lockdown for the pilot study for comprehending the scoring and analysis of the standardized scales. With due permission, a sample of total 64 female undergraduate students studying in a randomly selected (using lottery method) private degree college of Chandigarh was obtained. The sample was stratified further into two streams with24 in the humanities stream and 40 in the commerce stream respectively.

\section{STATISTICAL TECHNIQUES USED}

For a detailed preview of data, descriptive statistics including mean, standard deviation and standard error of mean have been used. Also, percentage analysis has been applied to depict the prevailing parenting style as perceived by female undergraduate students. Further, for the inferential statistics, datahas been analyzed by employing t-test and Pearson's product moment correlation to study the differences between the emotional intelligence of two streams and to determine the relationship between the emotional intelligence and parenting styles of female undergraduate students.

\section{RESULTS \& DISCUSSION}

Table 1. Prevailing parenting style as perceived by female undergraduate students

\begin{tabular}{|c|c|c|c|c|}
\hline Categories & Democratic & Permissive & Autocratic & Uninvolved \\
\hline Frequency & 47 & 9 & 7 & 1 \\
\hline Mean & 34.04 & 32.44 & 27.43 & 25.00 \\
\hline Std. Error of Mean & 0.88 & 0.85 & 1.46 & - \\
\hline Std. Deviation & 6.06 & 2.55 & 3.87 & - \\
\hline Percentage (\%) & 73.4 & 14.1 & 10.9 & 1.6 \\
\hline Rank & 1 & 2 & 3 & 4 \\
\hline
\end{tabular}

Table 1, depicts the means, standard deviations and percentage analysis of the parenting styles as perceived by female undergraduate students. The prevailing parenting style is democratic with mean=34.04, $\mathrm{SD}=6.06$ and percentage being 73.4\%, followed by permissive with mean $=32.44, \mathrm{SD}=2.55$ and percentage being $14.1 \%$, then autocratic with mean $=27.43, \mathrm{SD}=3.87$ and percentage being $10.9 \%$ lastly, uninvolved with mean $=25.00$ and percentage being $1.6 \%$. The results were supported by the studies done by Alt (2015) who depicted that the PalestinianArab young female participants perceived their parents to be more authoritative rather than authoritarian or permissive. Also study carried out by Shayo (2019) on females from Africa and Asia in a Chinese University revealed that authoritative parenting typology was the most 
Towards Excellence: An Indexed, Refereed \& Peer Reviewed Journal of Higher Education / Ms. Jaspreet

Kaur \& Dr. Gurmit Singh / Page 504-517

experienced parenting style in both continents in comparison to permissive and authoritarian were in consonance with the findings.

Table 2. Differences in the emotional intelligence of humanities and commerce female undergraduate students

\begin{tabular}{|c|c|c|c|c|c|c|c|}
\hline Stream & N & Mean & $\begin{array}{c}\text { Std. } \\
\text { Deviation }\end{array}$ & $\begin{array}{c}\text { Std. Error } \\
\text { Mean }\end{array}$ & t-value & p-value & $\begin{array}{c}\text { Level of } \\
\text { Significance }\end{array}$ \\
\hline Humanities & 24 & 2.81 & 26.56 & 5.42 & 2.42 & 0.02 & $\begin{array}{c}\text { Significant at } \\
0.05 \text { level }\end{array}$ \\
\hline Commerce & 40 & 2.15 & 17.99 & 2.85 & & & \\
\hline
\end{tabular}

Table 2, depicts the t-value of emotional intelligence is 2.42 at $\mathrm{df}=62$ alongwith the corresponding p-value being 0.02 . The value is significant at the 0.05 level only. Hence the alternate hypothesis is retained. It indicates that there is a significant difference between humanities and commerce female undergraduate students by further implying that humanities female undergraduate students (mean=2.81) have significantly higher emotional intelligence as compared to their commerce counterparts. The study done by Anitha and Jebaseelan (2014) on female first-year undergraduate arts students aged 18-20 years inferred less than half (i.e. $46 \%$ ) exhibited an overall poor while majority (54\%) portrayed overall good emotional intelligence was in consonance with the findings. However contrary to this, the study done by Jenifer (2012) on female college students from arts and science subjects in the age group of 1720 years depicted that they did not differ in emotional intelligence scores in relation to the subject specialization i.e. arts or science did not distinguish their emotional intelligence.

Table 3. Relationship between emotional intelligence and parenting styles as perceived by femaleundergraduate students $(\mathrm{N}=64)$

\begin{tabular}{|c|c|c|c|c|}
\hline Sr. No. & Variables & $\mathbf{r}$ & $\mathbf{p}$-value & Level of significance \\
\hline 1. & $\begin{array}{c}\text { Emotional Intelligence and } \\
\text { Democratic Parenting Style }\end{array}$ & 0.18 & 0.17 & Not Significant \\
\hline 2. & $\begin{array}{c}\text { Emotional Intelligence and } \\
\text { Autocratic Parenting Style }\end{array}$ & -0.004 & 0.98 & Not Significant \\
\hline 3. & $\begin{array}{l}\text { Emotional Intelligence and } \\
\text { Permissive Parenting Style }\end{array}$ & 0.11 & 0.37 & Not Significant \\
\hline 4. & $\begin{array}{c}\text { Emotional Intelligence and } \\
\text { Uninvolved Parenting Style }\end{array}$ & -0.23 & 0.07 & Not Significant \\
\hline
\end{tabular}

Table 3, depicts the r-values of emotional intelligence with the parenting styles as perceived by 
femaleundergraduate students (i.e. democratic, autocratic, permissive and uninvolved) as 0.18 , $-0.004,0.11$ and -0.23 respectively with $\mathrm{df}=62$ alongwith corresponding $\mathrm{p}$-values being $0.17,0.98,0.37$ and 0.07 . The value of the correlation coefficient for all the parenting styles as perceived by female undergraduate students is not significant. Hence the null hypothesis is retained. It indicates that there is no significant relationship between emotional intelligence and parenting styles (i.e. democratic, autocratic, permissive and uninvolved) as perceived female undergraduate students. The study by Alegare (2012) who found no correlations between the trait emotional intelligence measures and the two parental variables i.e. positive parenting and negative parenting. Further, ANOVA analysis depicted no significant differences in the trait emotional intelligence of the children among the four parenting styles i.e. authoritative, authoritarian, permissive and uninvolved was in consonance with the findings. However, contrary findings were reported to this in the studies done by Shalini and Balakrishna Acharya (2013) who indicated that father's authoritative and authoritarian parenting style was significantly related to emotional intelligence and fathers were perceived to be more authoritative towards girls than boys. Also, Salimynezhada, Yusef Poor and Valizade (2015) in their study revealed there were positive associations between all parenting styles and emotional intelligence. Female student's authoritarian parenting style had greater positive relations with emotional intelligence than that of males. Also, Priya and Jaswanti (2020) in their study on late adolescents in Chennai depicted that there was a positive correlation between parenting styles (namely permissive, authoritarian and authoritative) and emotional intelligence.

\section{CONCLUSIONS}

On the basis of the findings, following are the conclusions:

- There exists prevailing democratic parenting style as perceived by female undergraduate students.

- There exist significant differences as humanities female undergraduate students have significantly higher emotional intelligence as compared to commerce female undergraduate students.

- There exists no significant correlation between emotional intelligence and parenting styles (i.e. democratic, autocratic, permissive and uninvolved) as perceived by female undergraduate students.

\section{EDUCATIONAL IMPLICATIONS}

Based upon the present research, a replicated study can be conducted on a larger sample, other streams and different area as well. Along with the above said conditions advancedstatistical techniques can be used. Parents not only nurture the child but help them in the effective management of their emotions. Efficient parenting needs to include freedom and autonomy being provided to the child but within the prescribed limits. It has to be a two-way interaction also; 
Towards Excellence: An Indexed, Refereed \& Peer Reviewed Journal of Higher Education / Ms. Jaspreet

Kaur \& Dr. Gurmit Singh / Page 504-517

parents should pay extra attention towards their child's needs which will lead to the development of emotionally stable individuals. The parents of college level students should try to develop a bond of friendship for understanding and regulating the emotional needs ofthe child. Teachers, educational authorities and policy makers need to design training and awareness programmes especially for parents to comprehend their child's necessities. Intervention and educational initiatives for parents should also be arranged which must focus on their behaviours to enhance parental responsiveness towards their children for effective outcomes. As these could lead to the prevention of mismanagement of emotions associatedwith faulty patterns of parenting which in turn can assist the children to become healthy and happy. Also, as emotional intelligence can be learned and acquired, so parents should make every effort to train their wards for the effective management of emotions. 
Towards Excellence: An Indexed, Refereed \& Peer Reviewed Journal of Higher Education / Ms. Jaspreet

Kaur \& Dr. Gurmit Singh / Page 504-517

\section{References}

Alegre, B. (2012). Is there a relation between mothers' parenting styles and children's trait emotional intelligence. Electronic Journal of Research in Educational Psychology, 10, 5-34. Retrieved August 27, 2019, from https://core.ac.uk/download/pdf/143457083.pdf

Alt, D. (2015). First-year female college students' academic motivation as a function of perceived parenting styles: A contextual perspective. Journal of AdultDevelopment, 22, 63-75. https://doi.org/10.1007/s10804-014-9201-2

Anitha, P., \& Jebaseelan, A. U. S. (2014). A study on emotional intelligence among adolescent women college students at Tiruchirapalli. Indian Journal of Applied Research, 4 (12), 175 177. Retrieved February 1, 2020, from http://worldwidejournals.com/indian- journal-ofapplied-research-

(IJAR)/special_issues_pdf/December_2014_1418821577_57.pdf

Argyriou, E., Bakoyannis, G., \& Tantaros, S. (2016). Parenting styles and trait emotional intelligence in adolescence. Scandinavian Journal of Psychology, 57(1), 42-49. https://onlinelibrary.wiley.com/doi/abs/10.1111/sjop.12266

Barnhart, C.M., Raval, V.V., Jhansari, A., \& Raval, P.H. (2012). Perceptions of parenting style among college students in India and the United States. Journal of Child and Family Studies, 22(5), 684-693. Retrieved September 3, 2019, from https://www.researchgate.net/publication/257578477_Perceptions_of_Parenting_Style_ Among_College_Students_in_India_and_the_United_States

Baumrind, D. (1966). Effects of authoritative parental control on child behavior. Child Development, 37(4), 887-907. https://doi.org/10.2307/1126611

Biradar, S., \& Shashikumar, S. (2014). Status of emotional intelligence among the college students. Asian Journal of Home Science, 9(1), 241-245. Retrieved January 1, 2019, from http://researchjournal.co.in/online/AJHS/AJHS\%209(1)/9_241-245_A.pdf

Cameron, M., Cramer, K., \& Manning, D. (2020). Relating parenting styles to adult emotional intelligence: A retrospective study. Athens Journal of Social Sciences, 7(3), 185-196. https://doi.org/10.30958/ajss.7-3-3

Chaubey, D. S., \& Kala, D. (2012). Emotional intelligence among students: A comparative study of engineering and management disciplines. Uttaranchal Business Review, 2(1), 77-90. Retrieved December 29, 2019, from https://www.researchgate.net/publication/281405269_Emotional_Intelligence_Among_ Students_A_Comparative_Study_of_Engineering_and_Management_Discipline 
Cho, Y., \& Oh, I. (2019). The relation of life goal types and life satisfactions depending on perceived types of parenting style by college students. Korean Association for Learner-Centered Curriculum and Instruction, 19(11), 1327-1346. https://doi.org/10.22251/jlcci.2019.19.11.1327

Darling, N., \& Steinberg, L. (1993). Parenting style as context: An integrative model. Developmental Psychology, 113(3), 487-496. Retrieved February 5, 2021, from http://citeseerx.ist.psu.edu/viewdoc/download?doi=10.1.1.865.7470\&rep=rep1\&type=pd f

Descriptive Survey. (1981). Marilyn Zurmuehlen Working Papers in Art Education, 1(1), 54-63. doi:10.17077/2326-7070.1025

Fida, A., Ghaffar, A., Zaman, A., \& Satti, A. (2018). Gender comparison of emotionalintelligence of university students. Journal of Education and Educational Development,5(1), 172188. Retrieved January 29, 2021, from https://www.researchgate.net/publication/326267080_Gender_Comparison_of_Emotion al_Intelligence_of_University_Students.

Holt, S., \& Jones, S. (2005). Emotional intelligence and organizational performance: Implications for performance consultants and educators. Performance Improvement, 44(10), 15-23. doi:10.1002/pfi.4140441005

Gardner, H. (1983). Frames of mind: The theory of multiple intelligences (10th Anniversary Edition). New York: Basic Books. Retrieved December 29, 2019, from http://powervina.vn/media/1109/frames-of-mind-the-theory-of-mi.pdf

Gupta, M., \& Mehtani, D. (2017). Manual for parenting style scale. Agra: National Psychological Corporation.

Jayashree, S., Vimal Ram, S., \& Arun, M. D. (2018). Emotional Intelligence among college students with special reference to Kerala. International Journal of Pure and Applied Mathematics, 118(20), 4583-4589. Retrieved December 29, 2019, from http://www.acadpubl.eu/hub/2018-118-21/articles/21f/9.pdf

Jenifer, N. (2012). Emotional intelligence of female college students in relation to selected dimensions (Doctoral Thesis, Mother Teresa Women's University, Tamil Nadu).Retrieved February 1, 2021, from http://hdl.handle.net/10603/265107

Kaur, S. (2016). Manual for sevenfold emotional intelligence scale. Agra: H. P. Bhargava Book House.

Khajeh, N., \& Shayof D. (2015). The predictive role of parenting styles in emotional intelligence of students. Iran Journal of Nursing, 28(97), 66-76. Retrieved September 10, 2018, from http://ijn.iums.ac.ir/browse.php?a_id=2238\&sid=1\&slc_lang=en 
Towards Excellence: An Indexed, Refereed \& Peer Reviewed Journal of Higher Education / Ms. Jaspreet Kaur \& Dr. Gurmit Singh / Page 504-517

Kunnanatt, J. (2004). Emotional intelligence: The new science of interpersonal effectiveness. Human Resource Development Quarterly, 15(4), 489-495. Retrieved December 29, 2019 ,

from https://citeseerx.ist.psu.edu/viewdoc/download?doi=10.1.1.390.3615\&rep=rep1\&type=p df

Lau, S. R., Beilby, J., Byrnes, J. M., \& Hennessey, N. W. (2012). Parenting styles and attachment in school-aged children who stutter. Journal of Communication Disorders, 45(2), 110. Retrieved February 2021, from https://isiarticles.com/bundles/Article/pre/pdf/33541.pdf

Lin, Y. C., \& Billingham, R. E. (2014). Relationship between parenting styles and gender role identity in college students. Psychological Reports, 114(1), 250-271. Retrieved August 27, 2019 from https://pdfs.semanticscholar.org/aead/974a430495569649958574eb6dd150153820.pdf

Mayer, J. D., Caruso, D., \& Salovey, P. (1999). Emotional intelligence meets traditionalstandards for an intelligence. Intelligence, 27, 267-298. Retrieved February 5, 2021, from http://www.gruberpeplab.com/teaching/psych131_fall2013/documents/13.1_Mayer_200 0_EmotionIntelligenceMeetsStandardsForTraditionalIntelligence.pdf

Mayer, J. D., \& Salovey, P. (1997). What is emotional intelligence? In P. Salovey \& D. Sluyter (Eds.), Emotional development and emotional intelligence: Educational implications (pp. 3-31). New York, NY: Basic Books. Retrieved January 1, 2019, from http://ei.yale.edu/wpcontent/uploads/2014/02/pub219_Mayer_Salovey_1997.pdf

Mohammadyari, G., \& Sherzvani, R. (2013). The relationship between parental styles and emotional intelligence among students. Journal of Behavioral Sciences in Asia, 5, 19-

24. Retrieved January, 13, 2021, from https://citeseerx.ist.psu.edu/viewdoc/download?doi=10.1.1.593.4298\&rep=rep1\&type=p df

Moshahid, M. (2017). A comparative study of emotional intelligence among management and engineering students. International Journal of Academic Research and Development, 2(4), 716-720. Retrieved December 29, 2019, from www.academicjournal.in/download/653/2-5-87-985.pdf

Nastasa, L. E., \& Sala, K. (2012). Adolescents' emotional intelligence and parental styles. ProcediaSocial and Behavioral Sciences, 33, 478-482. https://www.sciencedirect.com/science/article/pii/S1877042812001759

Park, Y. S., Kim, B. S. K., Chiang, J., \& Ju, C. M. (2010). Acculturation, enculturation, parental adherence to Asian cultural values, parenting styles, and family conflict among Asian 
Towards Excellence: An Indexed, Refereed \& Peer Reviewed Journal of Higher Education / Ms. Jaspreet Kaur \& Dr. Gurmit Singh / Page 504-517

American college students. Asian American Journal of Psychology, 1(1), 67-79. https://doi.org/10.1037/a0018961

Priya, D., \& Jaswanti, V. P. (2020). Relationship between parenting styles and emotional intelligence among late adolescents in Chennai. International Journal of IndianPsychology, 8(2), 191-196. DOI:10.25215/0802.023

Salimynezhada, S., Poorb, N. Y., \& Valizade, A. (2015). The studies of relationship between parental styles with emotional intelligence in elementary schools students of Makoo.Social and Behavioral Sciences, 205, 221 - 227. Retrieved September 10, 2019, from https://core.ac.uk/download/pdf/81926166.pdf

Shalini, A., \& Balakrishna Acharya, Y. T. (2013). Perceived paternal parenting style on emotional intelligence of adolescents. Guru Journal of Behavioural and Social Sciences, 1(4), 194202. Retrieved August 18, 2019, from https://pdfs.semanticscholar.org/572a/62cad7d4f871a42380286ddf6dd1b572d7b2.pdf

Shayo, H. (2019). Parenting styles as a gateway for girls education accomplishment: A case study of female African and Asian students in a Chinese university. In Advances in Social Science, Education and Humanities Research (Proceedings of the 2nd Symposium on Health and Education 2019), Atlantis Press, 424-433. https://doi.org/10.2991/sohe19.2019 .71

Walsh-Portillo, J. G. (2011). The role of emotional intelligence in college students' success(Doctoral dissertation, Florida International University Miami, Florida). Retrieved September 3, 2019 , from http://digitalcommons.fiu.edu/etd/491

Wischerth, G. A., Mulvaney, M. K., Brackett, M. A., \& Perkins, D. (2016). The adverse influence of permissive parenting on personal growth and the mediating role of emotional intelligence. Journal of Genetic Psychology, 177(5), 185-189. DOI: $10.1080 / 00221325.2016 .1224223$

Yousefi, F. (2006). The relationship between emotional intelligence and communicational skills of university students. Developmental Psychology (Journal of Iranian Psychologists, 3(9), 5 13. Retrieved December 29, 2019, from https://www.sid.ir/en/journal/ViewPaper.aspx?ID=103120

Zakeri, H., \& Karimpour, M. (2011). Parenting styles and self-esteem. Procedia - Social and Behavioral Sciences, 29, 758-761. https://doi.org/10.1016/j.sbspro.2011.11.302 
Ms. Jaspreet Kaur

Research Scholar (SRF), Department of Education

Panjab University, Chandigarh

Contact Mail: jaspreetkaur081190@gmail.com

\&

Dr. Gurmit Singh

Associate Professor

Malwa Central College of Education for Women,Ludhiana.

Contact Mail: drgurmitsingh18@gmail.com 